\title{
Occurrence, Molecular Characterisation, and Pathogenicity of Neoscytalidium dimidiatum on Citrus in Italy
}

\author{
G. Polizzi, D. Aiello, I. Castello and A. Vitale \\ Dipartimento di Scienze e Tecnologie Fitosanitarie \\ University of Catania \\ Italy
}

\author{
J.Z. Groenewald and P.W. Crous \\ CBS-KNAW \\ Fungal Biodiversity Centre \\ Utrecht \\ The Netherlands
}

Keywords: Citrus sinensis, sour orange rootstock, shoot blight, gummosis, sooty canker

\begin{abstract}
During 2008 and 2009, a new disease was noticed in eastern Sicily (Italy) in two re-grafted citrus orchards (Citrus sinensis (L.) Osbeck) on sour orange rootstock. Symptoms consisted of blight of vigorously growing shoots and a sooty canker on shoots and rootstock trunks. A Scytalidium-like fungus was isolated consistently from symptomatic tissues on $2 \%$ potato-dextrose agar (PDA). The mycelium was composed of branched, septate, brown hyphae which disarticulated into 0-1-septate phragmospores. In culture it also produced a pycnidial synanamorph, with hyaline conidiogenous cells that were intermingled with paraphyses. Conidia were ellipsoid to ovoid, hyaline, with an acutely rounded apex, truncate base, initially aseptate, becoming brown and 2-septate at maturity, with the central cell darker than the end cells. Genomic DNA was extracted from mycelia of single-conidial isolates cultivated on $2 \%$ malt extract agar and the nuclear rRNA operon spanning the 3 ' end of $18 \mathrm{~S}$ rRNA gene, the internal transcribed spacers, the 5.8S rRNA gene, and a part of the 5' end of the $28 \mathrm{~S}$ rRNA gene was amplified and sequenced. On the basis of morphological characters and molecular data, the fungal isolates were identified as Neoscytalidium dimidiatum (Penz.) Crous \& Slippers. Koch's postulates were satisfied and confirmed the pathogenicity of the fungus. $N$. dimidiatum appears to pose a serious threat to re-grafted citrus orchards.
\end{abstract}

\section{INTRODUCTION}

In September 2008, a new disease was noticed in eastern Sicily (Italy) in a 2-yearold re-grafted citrus orchard of sweet orange [Citrus sinensis (L.) Osbeck] 'Tarocco Scirè' on sour orange rootstock. Symptoms on the sweet orange scion consisted of blight of vigorously growing shoots and a sooty canker on shoots and rootstock trunks, resulting in shoot dieback to the cankered area. Masses of black fungal spores appeared under the bark and on the canker surface. Abundant gummosis was frequently associated with the affected tissues. A Scytalidium-like fungus was isolated consistently from symptomatic tissues on $2 \%$ potato-dextrose agar (PDA). The objectives of this work were i) to determine the relationship of the Scytalidium-like fungus to shoot blight, canker, and gummosis, ii) evaluate the importance of this disease on re-grafted citrus orchards, and iii) the characterisation of the fungal isolates on the basis of morphological and molecular data.

\section{MATERIALS AND METHODS}

\section{Plant Disease Survey and Isolation Procedures}

Surveys were performed during 2008 and 2009 in citrus orchards located in Catania and Siracuse provinces in eastern Sicily (Italy) and re-grafted during the summer of 2006 and 2007. Several citrus samples showing blight of vigorously growing shoots and a sooty canker on shoots and rootstock trunks were randomly collected for further analysis. In addition, the percentage of symptomatic plants (disease incidence) in each citrus orchard was calculated.

Damaged tissues collected from symptomatic field plants were superficially 
disinfected with $1.0 \%$ sodium hypochlorite for $2 \mathrm{~min}$, rinsed, and placed in potato dextrose agar (PDA) at $21^{\circ} \mathrm{C}$.

\section{Morphology}

Preparations from cultured fungal colonies were mounted on glass slides with clear lactic acid for microscopic examination. Measurements of conidia and phragmospores (Neoscytalidium state) were made at $1,000 \times$ magnification, with 50 measurements per structure.

\section{Molecular Identification}

Genomic DNA was extracted from mycelia of fungal colonies cultivated on malt extract agar (MEA) using the UltraClean ${ }^{\mathrm{TM}}$ Microbial DNA Isolation Kit (Mo Bio Laboratories, Inc., Solana Beach, Ca, USA). The primers V9G (de Hoog and Gerrits van de Ende, 1998) and ITS4 (White et al., 1990) were used to amplify the nuclear rRNA operon spanning the 3' end of 18S rRNA gene, the internal transcribed spacers, the 5.8S rRNA gene, and a part of the 5' end of the 28S rRNA gene. Both PCR primers were used to sequence directly the entire amplicon. The PCR amplifications were performed on a GeneAmp PCR System 9700 in a total volume of $12.5 \mu$ l solution containing 10-20 ng of template DNA, $1 \times \mathrm{PCR}$ buffer, $2.5 \mathrm{mM} \mathrm{MgCl}$, 15 pmol for each primer, $60 \mu \mathrm{M}$ of each dNTP and 0.75 U Taq DNA polymerase (Bioline GmbH, Luckenwalde, Germany). The resulting fragments were sequenced using the PCR primers together with a BigDye Terminator Cycle Sequencing Kit v. 3.1 and analysed on an 3730 DNA Analyzer (Applied Biosystems, Warrington, UK).

The generated sequences were compared with other fungal DNA sequences from NCBI's GenBank sequence database using a megablast search of the nr database (Zhang et al., 2000). The alignment of Pavlic et al. (2008) was obtained from TreeBASE (matrix M4179; www.treebase.org) and used as starting point for the current study. The additional sequences were manually added to the TreeBASE matrix using Sequence Alignment Editor v. 2.0a11 (Rambaut, 2002) and redundant taxa removed from the alignment. The final alignment was confirmed and improved manually where necessary. The phylogenetic analyses of the aligned sequence data were performed using PAUP (Phylogenetic Analysis Using Parsimony) v. 4.0b10 (Swofford, 2003) and consisted of neighbour-joining analyses with the uncorrected ('p'), the Kimura 2-parameter and the HKY85 substitution models. Alignment gaps were treated as missing data and all characters were unordered and of equal weight. Any ties were broken randomly when encountered. For parsimony analyses, alignment gaps were treated as a fifth character state and all characters were unordered and of equal weight. The maximum parsimony analysis was performed using the heuristic search option with 100 random taxon additions and tree bisection and reconstruction (TBR) as the branch-swapping algorithm. Branches of zero length were collapsed and all multiple, equally parsimonious trees were saved. The robustness of the trees obtained was evaluated by 1,000 bootstrap replications (Hillis and Bull, 1993). Tree length (TL), consistency index (CI), retention index (RI) and rescaled consistency index (RC) were calculated and the resulting trees were printed with TreeView v. 1.6.6 (Page, 1996). New sequences were submitted to GenBank and the alignments and phylogenetic trees in TreeBASE.

\section{Pathogenicity Tests}

Pathogenicity tests were conducted on five 2-year-old potted plants of sweet orange 'Tarocco Scirè' and of lemon 'Femminello Zagara Bianca', both grafted on sour orange. Eight mycelial plugs of a single-conidial isolate $(5 \mathrm{~cm}$ diam), taken from the margin of an actively growing colony, were placed in wounds made with a sterile blade in the inner bark of plant stems and branches. The same number of plants inoculated with sterile PDA plugs served as controls. Following inoculation, the mycelial plugs, the stems and the branches were wrapped with Parafilm. All plants were maintained in a growth chamber at $25 \pm 1{ }^{\circ} \mathrm{C}$ and 90 to $95 \%$ relative humidity. 


\section{RESULTS AND DISCUSSION}

\section{Plant Disease Survey and Isolation Procedures}

During 2008 and 2009, the disease was detected in citrus orchards located in Lentini (Siracuse province) in two re-grafted citrus 'Tarocco Scirè' sweet orange orchards grafted on sour orange rootstock. Symptoms consisted of blight of vigorously growing shoots and a sooty canker on shoots and rootstock trunks. Masses of black fungal spores appeared under the bark, and on the canker surface. Abundant gummosis was frequently associated with the affected tissues. Of the 2,000 plants surveyed, $\sim 14 \%$ were infected. A Scytalidium-like fungus was isolated consistently from symptomatic tissues on PDA.

\section{Morphology}

The fungus proved to be dimorphic in culture. Conidiogenous cells of the pycnidial anamorph were hyaline, intermingled with paraphyses. Conidia were ellipsoid to ovoid, hyaline, with an acutely rounded apex, truncate base, initially aseptate, becoming brown and 2 -septate at maturity, (10-)12-13(-14) $\times(4-) 5(-6) \mu \mathrm{m}$, with the central cell darker than the end cells. Mycelium of the Neoscytalidium anamorph was composed of branched, septate, brown hyphae which disarticulated into 0-1-septate phragmospores.

\section{Molecular Identification}

Approximately 700 bases were obtained for isolates of the Scytalidium-like fungus. The manually adjusted ITS alignment contained 31 sequences (including the outgroup sequence) and, of the 605 characters (including alignment gaps) used in the phylogenetic analysis, 121 were parsimony-informative, 112 were variable and parsimony-uninformative and 372 were constant. Neighbour-joining analysis using the three substitution models on the alignment yielded trees with similar topology and bootstrap values (data not shown). Twelve equally most parsimonious trees were obtained from the heuristic parsimony search, the first of which is shown in Figure 1 (TL $=359$, CI $=0.825, \mathrm{RI}=0.921, \mathrm{RC}=0.760)$. The tree presented in Figure 1 differs with the obtained distance trees only with regard to some rearrangements at the deeper nodes; terminal clades and sister relationships of closely related clades were consistent.

Isolates of the Scytalidium-like fungus clustered in a clade (Fig. 1) with isolates of Neoscytalidium novaehollandiae Pavlic, T.I. Burgess \& M.J. Wingf., N. dimidiatum (Penz.) Crous \& Slippers and a sequence of the ex-type strain of Scytalidium hyalinum C.K. Campb. \& J.L. Mulder (strain ATCC 38906; GenBank AY213688). Pavlic et al. (2008) described the conidia of $N$. novaehollandiae as being of two distinct types, the first ellipsoidal to oval, (8-)10.5-12.5(-14) × (3-)4-5(-5) $\mu \mathrm{m}$ (av. 11.5×4.4 $\mu \mathrm{m}, 1 / \mathrm{w} 2.6$ ), apices rounded, initially hyaline, unicellular, becoming cinnamon to sepia, and 0-1septate or 2-septate with darker central cell; and the second being variable in shape, globose, subglobose to obpyriform with muriform septa, (8-)8.5-12.5(-15.5) $\times(5-) 5.5-$ $7.5(-8) \mu \mathrm{m}($ av. $10.6 \times 6.9 \mu \mathrm{m}, 1 / \mathrm{w} 1.5)$, initially hyaline becoming cinnamon to sepia. The aerial mycelium of $N$. novaehollandiae formed chains of unicellular arthroconidia which were disarticulating, cylindrical, oblong to obtuse to doliiform, thick-walled, initially hyaline becoming cinnamon to sepia and 0-1-septate. Pavlic et al. (2008) distinguished $N$. novaehollandiae from $N$. dimidiatum based on the former's ability to produce muriform, Dichomera-like conidia, that are absent in $N$. dimidiatum. The taxonomic history of $N$. dimidiatum was discussed by Crous et al. (2006). S. hyalinum is considered to be a variety (Madrid et al., 2009) or a melanin-deficient cultural mutant (Roeijmans et al., 1997) of $N$. dimidiatum.

\section{Pathogenicity Tests}

After 2 weeks all inoculated plants developed gummosis originating from the inoculation point. Shoot blight and death of the entire plant were observed within 6months on all inoculated plants (Fig. 2). No differences were observed among the citrus 
species. Control plants remained healthy. $N$. dimidiatum was always reisolated from the infected plants and identified as previously described.

$N$. dimidiatum has been reported on diverse woody plants (Punithalingam and Waterston, 1970; Sutton and Dyko, 1989, Farr et al., 2004) and occasionally is isolated from human skin and nails (Moore, 1988; de Hoog et al., 1998). Although reported to be cosmopolitan, the diseases caused by this fungus tend to occur in tropical countries.

On citrus the pathogen has been previously observed to infect freeze-damage limbs in California, inducing a disease named Hendersonula branch wilt (Whiteside, 1988). This pathogen is important chiefly as a wound pathogen that has been damaged by freezing injury, sunburn, or mechanical injury but does not infect uninjured bark tissue (Calavan and Wallace, 1954).

Penzig's (1887) meager description of Torula dimidiata on lemon in Italy indicates that a fungus similar to and possibly identical with the toruloid form of $N$. dimidiatum has been present in the Mediterranean region for at least 120 years.

To our knowledge, these are the first data on occurrence, molecular characterisation, and pathogenicity of the disease caused by $N$. dimidiatum on citrus in Italy. This fungus may pose a serious threat to re-grafted citrus orchards.

\section{Literature Cited}

Calavan, E.C. and Wallace, J.M. 1954. Hendersonula toruloidea Natrass on citrus in California. Phytopathology 44:635-639.

Crous, P.W., Slippers, B., Wingfield, M.J., Rheeder, J., Marasas, W.F.O., Phillips, A.J.L., Alves, A., Burgess, T., Barber, P. and Groenewald, J.Z. 2006. Phylogenetic lineages in the Botryosphaeriaceae. Studies in Mycology 55:235-253.

de Hoog, G.S. and Gerrit van den Hende, A.H.G. 1998. Molecular diagnostics of clinical strains of filamentous basidiomycetes. Mycoses 41:183-189.

Farr, D.F. and Rossman, A.Y. Fungal Databases, Systematic Mycology and Microbiology Laboratory, ARS, USDA. Retrieved January 5, 2010, from http://nt.ars-grin.gov/ fungaldatabases/

Hillis, D.M. and Bull, J.J. 1993. An empirical test of bootstrapping as a method for assessing confidence in phylogenetic analysis. Systematic Biology 42:182-192.

Madrid, H., Ruíz-Cendoya, M., Cano, J., Stchigel, A., Orofino, R. and Guarro, J. 2009. Genotyping and in vitro antifungal susceptibility of Neoscytalidium dimidiatum isolates from different origins. International Journal of Antimicrobial Agents 34:351354.

Moore, M.K. 1988. Morphological and physiological studies of isolates of Hendersonula toruloidea Natrass cultured from human skin and nail samples. Journal of Medical and Veterinary Mycology 26:25-39.

Page, R.D.M. 1996. TREEVIEW: An application to display phylogenetic trees on personal computers. Computer Applications in the Biosciences 12:357-358.

Pavlic, D., Wingfield, M.J., Barber, P., Slippers, B., Hardy, G.E.St.J. and Burgess T. I. 2008. Seven new species of the Botryosphaeriaceae from baobab and other native trees in Western Australia. Mycologia 100:851-866.

Penzig, O. 1887. Studi botanici sugli agrumi e sulle piante affini. Memoria Premiata dal R. Minister dell'Agricoltura (Dagli Annali di Agricoltura 1887.) Tipografia Eredi Botta, Rome, Italy, 590p.

Punithalingam, E. and Waterston, J.M. 1970. Hendersonula toruloidea. C.M.I. Descript. Pathog. Fungi Bact. 274:1-2.

Rambaut, A. 2002. Sequence Alignment Editor. Version 2.0. Department of Zoology, University of Oxford, Oxford, United Kingdom.

Roeijmans, H.J., De Hoog, G.S., Tan, C.S. and Figge, M.J. 1997. Molecular taxonomy and GC/MS of metabolites of Scytalidium hyalinum and Nattrassia mangiferae (Hendersonula toruloidea). Journal of Medical and Veterinary Mycology 35:181-188.

Sutton, B.C. and Dyko, B.J. 1989. Revision of Hendersonula. Mycological Research 93:466-488. 
Swofford, D.L. 2003. PAUP*. Phylogenetic analysis using parsimony (*and their methods). Version 4. Sinauer Associates, Sunderland, Massachusetts.

White, T.J., Bruns, T., Lee, J. and Taylor, J. 1990. Amplification and direct sequencing of fungal ribosomal RNA genes for phylogenetics. p.315-322. In: M.A. Innis, D.H. Gelfand, J.J. Sninsky and T.J. White (eds.), PCR protocols: a guide to methods and applications, Academic Press, San Diego, California, USA.

Whiteside, J.O. 1988. Miscellaneous fungi and associated diseases. p.29. In: J.O. Whiteside, S.M. Garnsey and L.W. Timmer (eds.), Compendium of Citrus Diseases, The American Phytopathological Society, St. Paul, Minnesota, USA.

Zhang, Z., Schwartz, S., Wagner, L. and Miller, W. 2000. A greedy algorithm for aligning DNA sequences. Journal of Computational Biology 7:203-214. 


\section{Figures}

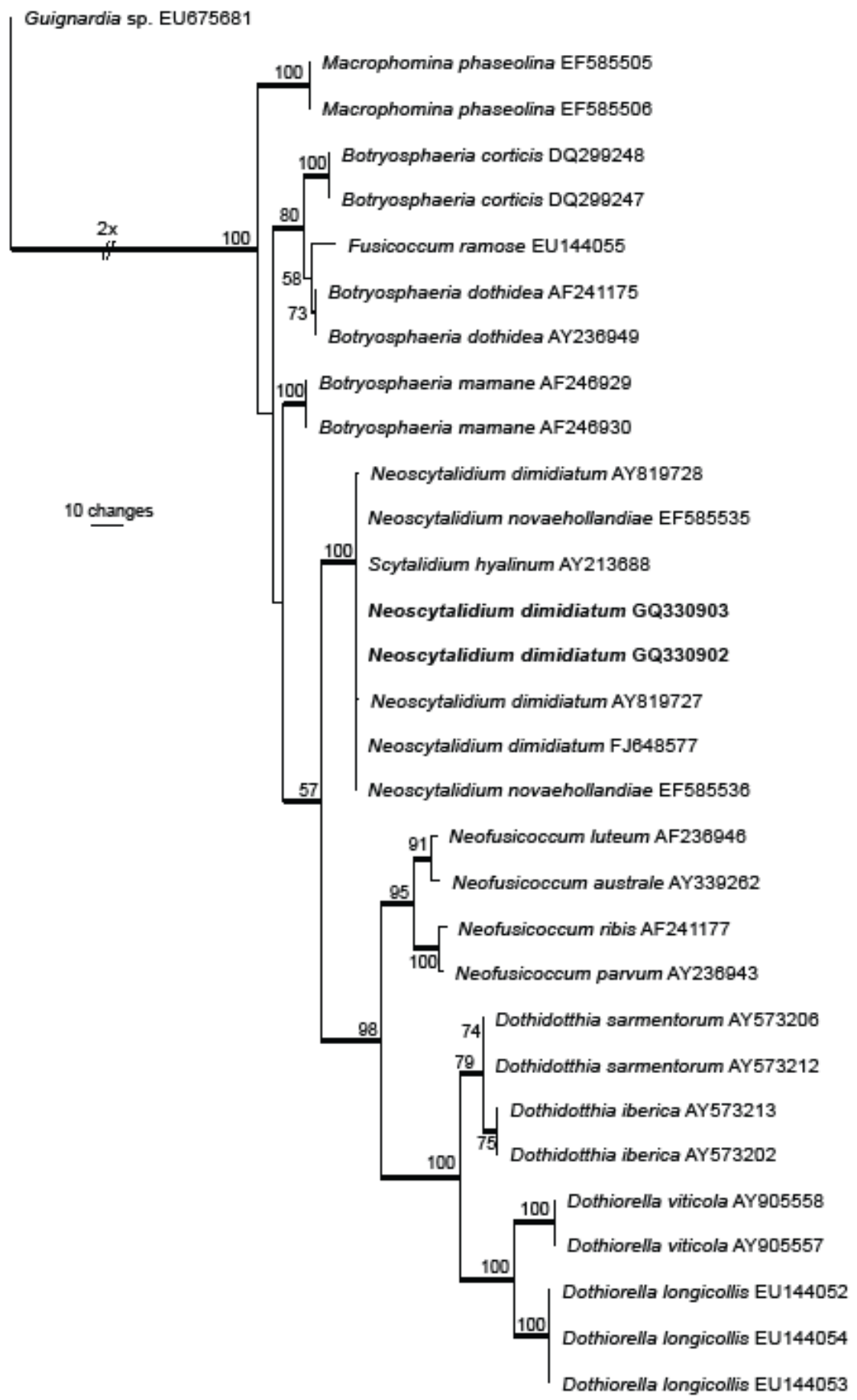

Fig. 1. The first of 12 equally most parsimonious trees obtained from a heuristic search with 100 random taxon additions of the sequence alignment using PAUP v. 4.0b10. The scale bar shows 10 changes and bootstrap support values from 1,000 replicates are shown at the nodes. Thickened lines indicate the strict consensus branches and the two sequences obtained from the Scytalidium-like fungal isolates are printed in bold. The tree was rooted to Guignardia sp. (GenBank accession EU675681). 


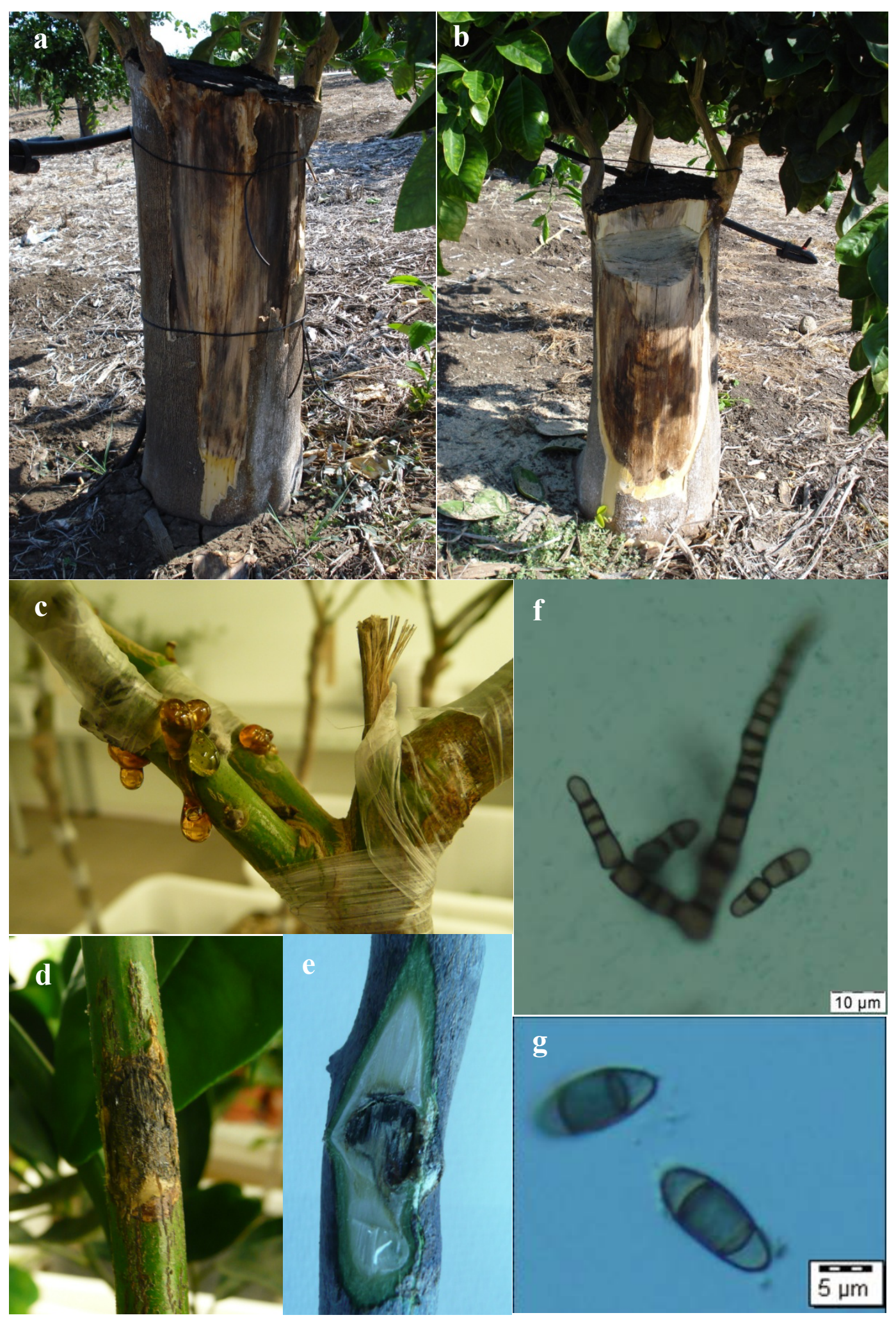

Fig. 2. a, b) Sooty canker and gummosis caused by Neoscytalidium dimidiatum; c, d, e) Gummosis, sooty canker and layer of arthrospores under periderm of shoot on inoculated plants; f) Phragmospores; and g) Conidia. 